\title{
South Asia suffers severe water scarcity even under the Paris Agreement
}

\section{Mehnaz Rashid}

National Taiwan University https://orcid.org/0000-0002-0602-5298

\section{Ren-Jie Wu}

National Taiwan University

\section{Yoshihide Wada}

The International Institute for Applied Systems Analysis https://orcid.org/0000-0003-4770-2539

\section{Hannes Müller Schmied}

Goethe University Frankfurt https://orcid.org/0000-0001-5330-9923

Min-Hui Lo ( $\nabla$ minhuilo@ntu.edu.tw )

Department of Atmospheric Sciences, National Taiwan University, Taipei, Taiwan

https://orcid.org/0000-0002-8653-143X

\section{Article}

Keywords:

Posted Date: February 11th, 2022

DOI: https://doi.org/10.21203/rs.3.rs-1293828/v1

License: (c) (i) This work is licensed under a Creative Commons Attribution 4.0 International License.

Read Full License 
South Asia suffers severe water scarcity even under the Paris

Agreement

$8 \quad{ }^{1}$ Mehnaz Rashid (geo.mehnaz@gmail.com)

$9{ }^{1}$ Department of Atmospheric Sciences, National Taiwan University, Taipei, Taiwan

$10 \quad{ }^{1}$ Ren-Jie Wu (wurjicnip@gmail.com)

$11{ }^{1}$ Department of Atmospheric Sciences, National Taiwan University, Taipei, Taiwan

$12 \quad{ }^{2}$ Yoshihide Wada (wada@iiasa.ac.at)

$13{ }^{2}$ International Institute for Applied Systems Analysis (IIASA), Laxenburg, Austria

$14 \quad{ }^{3,4}$ Hannes Müller Schmied (Hannes.Mueller.Schmied@em.uni-frankfurt.de)

$15{ }^{3}$ Institute of Physical Geography, Goethe University Frankfurt, Frankfurt, Germany

$16{ }^{4}$ Senckenberg Leibniz Biodiversity and Climate Research Centre (SBiK-F), Frankfurt, Germany

$17 \quad{ }^{1}$ Min-Hui Lo (minhuilo@ntu.edu.tw)

$18{ }^{1}$ Department of Atmospheric Sciences, National Taiwan University, Taipei, Taiwan 
Letter:

40 Water scarcity (WS) is projected to increase as a result of future climate and population

41 changes, and its impacts will be hazardous to vulnerable groups of people in South Asia (SA).

42 We present the first assessment of WS in SA under the Paris Agreement, using two global

43 hydrological models (GHM) forced by three global climate models (GCM) under the RCP

$44 \quad 6.0$. Results show that a significant alteration in the hydrological fluxes contributes to the

45 decline in water availability, along with an intense increase in water consumption that

46 augments WS. The seasonal shifting in WS significantly increases the population affected by

47 approximately $16 \%$ in June to September (JJAS) to $42 \%$ in December to February (DJF)

48 under $1.5^{\circ} \mathrm{C}$ warming. We also highlight spatial hotspots of WS in SA, including North-

49 central, Northwestern, and Southern India, Eastern Pakistan, Northern, and Northwestern

50 Bangladesh. We observe a $1.5^{\circ} \mathrm{C}$ temperature increase as a critical point for WS in SA with

51 a profound impact on 875 million people and suggest the Paris Agreement temperature

52 target of even $1.5^{\circ} \mathrm{C}$ will not ubiquitously alleviate future warming-driven WS. Hence,

53 immediate mitigations and legislations are required to curtail WS in SA. 
65 Climate change and its effects represent an immediate threat to human society and the 66 environment ${ }^{1}$. Considering the substantial dangers associated with increasing temperatures, the 67 Paris Agreement 2015 enshrined a two-tier global temperature control goal: limiting global 68 warming to $1.5^{\circ} \mathrm{C}$ and holding the increase below $2{ }^{\circ} \mathrm{C}$ above pre-industrial levels recognizing that 69 this would significantly reduce the risks and impacts of climate change ${ }^{2}$. Water scarcity has emerged as one of the major threats to societal wellbeing due to its direct impact on food and water security, socioeconomics, and hydroclimate ${ }^{3-5}$. Since the last century, an increase in anthropogenic 72 warming and water consumption has aggravated WS in many parts of the world ${ }^{6-10}$. Similarly, 73 future projections suggest a substantial increase in WS as a result of climate change and population 74 increase $e^{4,5,11-16}$, particularly in vulnerable regions like South and East Asia, the Middle East, 75 Central, and Western North America, parts of Australia, and Northern Africa ${ }^{5,6,9,13,15-19}$. The number of people affected, however, depends greatly on the assessment method, time frame, and the reference period used ${ }^{5-7,16}$. Thus, using annual WS assessments could mask the number of people affected, over-shadowing particular seasons of the year in which WS occurs ${ }^{5,6}$. Particularly, water availability changes seasonally in sub-tropical and tropical regions due to monsoonal rainfall and river discharge changes ${ }^{15,20,21}$. Therefore, WS and the changes in the hydrological components

81 should be evaluated on a seasonal scale.

There are two primary contributors to WS: 1) decline in water availability and 2) increase in water consumption. Anthropogenic warming results in declines in the availability of freshwater resources in many regions by altering the terrestrial hydrological cycle (precipitation, ET, and discharge $)^{20,22-25}$. On the other hand, increasing population and changing socioeconomics lead to increases in per capita freshwater consumption ${ }^{18,26-29}$. However, the impact of climate change

88 largely depends on the vulnerability of the people and their resilience. For example, people living in densely populated and/or lower and medium income regions are at greater risk of weather and 90 climate hazards $1,18,24$.

92 With a population of 1.8 billion people ${ }^{30}$, South Asia (SA) has been identified as one of the most 93 susceptible regions for climate (such as water stress, floods, drought, and heat stress) and 94 socioeconomic vulnerability ${ }^{15,31-34}$. Saeed et al. $(2021)^{31}$ reported an extreme severity in the heat 95 stress across $\mathrm{SA}$ at $1.5^{\circ} \mathrm{C}$ global warming, making this low warming goal undesirable for the South 
Asian Region. In the middle of the road Shared Socioeconomic Pathways, or SSP2 projections,

97 the South Asian population is expected to reach around 2 billion around $1.5^{\circ} \mathrm{C}$ global temperature increases above pre-industrial level, exerting further pressure on the water resources and food

99

100

101

102

103

104

105

106

107

108

109

110 security. For instance, India, the largest country in the region with a current population of 1.3 billion, is already facing acute water shortage ${ }^{8,32,35}$, with about 600 million people presently living under extreme $\mathrm{WS}^{34}$. Water availability in India, Pakistan, and Bangladesh is projected to decline considerably by $2030^{34,36,37}$. Severe water demand has resulted in significant groundwater exploitation in the region, leading to overexploitation of the prominent aquifers ${ }^{38,39}$. The concurrent impacts of rising temperatures, $\mathrm{CO}_{2}$ concentrations ${ }^{40}$, and population ${ }^{41}$ have resulted in a decline in freshwater resources and caused an extreme WS.

Several studies have analyzed contemporary and future WS assessments globally and regionally ${ }^{5,15,16,26,28,33,42-44}$. However, only a few studies focus on the seasonal WS assessment in SA; for example, Satoh et al. (2017) ${ }^{15}$ reported a substantial seasonal variation in WS in 2050 compared to 2010. Overall, the seasonal variations in the WS and the hydrological fluxes in SA in the context of the Paris Agreement $\left(1.5\right.$ and $2{ }^{\circ} \mathrm{C}$ of temperature increase compared to the preindustrial period) are poorly known. The preeminent reason is the dearth of required data for these warming scenarios ${ }^{45}$. It is thus indispensable to understand how WS will manifest in this largely populated region under Paris temperature targets. Therefore, this study aims to assess the changes in the seasonal and spatial patterns of WS and hydrological fluxes. We explore the number of people affected by various degrees of WS in the 1.5 and $2{ }^{\circ} \mathrm{C}$ warming scenarios under SSP2 population and RCP 6.0 climate projections using Inter-Sectoral Model Intercomparison Project Phase $2 b$ (ISIMIP2 $b^{46}$ ) model simulations. Total water availability and water consumption are calculated seasonally, taking a 31-year mean from an ensemble GHM-GCM simulations. According to the climatological cycle in SA, we separate the year into 4 different periods, which are from June to September (JJAS), October to November (ON), December to February (DJF), and March to May (MAM). Total water availability is estimated as the sum of discharge and water consumption in each grid, and water consumption is the sum of water use from each sector. Furthermore, we evaluate the control of hydrological variables (i.e., precipitation and ET) on WS using linear regression analysis. A comprehensive description of scenario analysis, including how WS is defined and calculated is given in the Methods section. 


\section{Results}

128 Results from the ensemble of two hydrological and three climate models show that WS in SA will 129 increase significantly in a $1.5^{\circ} \mathrm{C}$ warming scenario with a robust spatiotemporal variability (Fig. 130 1a), and the absolute changes compared to the pre-industrial period are considerable (Fig. 1b).

131 Spatial WS hotspots in the region are located in North-central, Northwestern and Southern India, 132 Eastern Pakistan, Northern, and Northwestern Bangladesh; given the socio-economic situation, 133 these areas can be most vulnerable to water crises in the future. On the other hand, the Himalayan 134 region (Nepal, Bhutan, North and Northeastern India, and Northern Pakistan), Central-eastern 135 India, Western Pakistan, and most of Sri Lanka are relatively unaffected. A robust seasonality in 136 WS is observed, which is lowest in JJAS and peaks in DJF and MAM (Fig.1). To explore how 137 strongly seasonality affects water security in the future, Table 1 shows the exposure of the human 138 population to WS in each season. For example, in JJAS, 157 million (7.6\% of the total population 139 in SA) people are projected to face severe WS, and the number increases to 341 million (16.5\%), 140610 million (29.4\%), and 558 million (28.4\%) in ON, DJF, and MAM, respectively. Of the 141 numbers mentioned above, India alone is projected to have 494 million (31.3\% of the total 142 population in India) and 503 million (31.8\%) people under severe WS in DJF and MAM, 143 respectively (Table 1 and Supplementary Table 1).

145 We observe a considerable increase in the number of people living under severe WS in a $1.5^{\circ} \mathrm{C}$ 146 warmer world compared to the pre-industrial period. For example, population living under severe 147 WS will increase from $1.5 \%$ to $7.6 \%, 3.7 \%$ to $16.5 \%, 5 \%$ to $29.4 \%$, and $6 \%$ to $28.4 \%$ ( $\%$ of total 148 population) in JJAS, ON, DJF, and MAM, respectively (Table 1 and Supplementary Table 1). The 149 South Asian population for the pre-industrial reference period (1660-1860) is 286 million, and it 150 is expected to increase 7 -fold around the $1.5^{\circ} \mathrm{C}$ warming period under SSP2 population projections 151 and reach 2 billion.

153 Please note that the individual GCMs cross the $1.5{ }^{\circ} \mathrm{C}$ temperature thresholds in different periods 154 compared to the pre-industrial reference period. Thus, we calculate the population affected by the 155 different WS grades corresponding to the central 31-year temperature threshold for individual 156 GCMs and subsequently use the ensemble population values for our analysis (see Methods). 
157 Altogether, about $42 \%$ of the South Asian population will suffer from moderate to severe WS for 158 half of the year (Table 1). This will result in water crises in this already vulnerable region with 159 severe over-exploitation of freshwater resources. WS in both 1.5 and $2{ }^{\circ} \mathrm{C}$ warming scenarios is 160 analogous compared to the pre-industrial period and additional warming of $0.5^{\circ} \mathrm{C}$ does not reveal 161 a significant change in WS pattern (Fig. 1b, Supplementary Fig. 1b). This is primarily due to stable 162 levels of discharge (Supplementary Figs. $2 \mathrm{~b}$ and $3 \mathrm{~b}$ ) along with the counterbalance of increased 163 precipitation (Supplementary Figs. 2a and 3a) by the increase in ET (Supplementary Figs. 2c and 164 3c). A slight increase in the total number of people affected is observed mainly due to the increase in the total population (Supplementary Table 2).

167 Two major factors affecting the WS in a warmer world are water availability and water 168 consumption (Fig. 2). Water availability shows enormous heterogeneity in its seasonal and spatial 169 patterns, and the absolute changes compared to the pre-industrial period are extensive (Fig. 2a). 170 JJAS is the most plentiful water season, with the average availability going up to $1200 \mathrm{~mm}$ in some 171 of the prominent river basins (Supplementary Fig. 4a), signifying the importance of both summer 172 monsoon (which supplies approximately $80 \%$ of the rainfall to the region) ${ }^{47}$ and river discharge 173 that is maximum during the summer season ${ }^{21}$. However, compared to the pre-industrial period, 174 water availability in JJAS declines in the Himalayan region, North-central, Northwestern and 175 Southern India, Eastern Pakistan, and Bangladesh. This region abodes important rivers like the 176 Indus, Ganges, and Brahmaputra in the north, and Krishna and Cauvery in the south. The decrease 177 of water availability in these areas is likely due to decreases in the discharge and/or precipitation 178 (Supplementary Figs. 3a and 3b). Fig. 2 further indicates that during ON, declines are observed in 179 North-central India, Eastern Himalayas, and Western Bangladesh. A slightly increasing trend is 180 observed in the rest of SA (e.g., Western Himalayas, Sri Lanka, and most parts of South and 181 Central India). During DJF, the Western Himalayan region shows a slight increase in availability, 182 while the Eastern Himalayan region and Northeastern Pakistan show a modest decrease. During 183 MAM, the Himalayan region and Eastern Bangladesh show an increasing trend, and North-central 184 India and East Pakistan show a slight increase in water availability.

186 Likewise, consumption projections show significant increases over most of SA compared to the 187 pre-industrial period (Fig. 2b). The spatial pattern during JJAS and ON reveals the increased 
consumption over North-central and Northwestern India, the most populated regions, along with

189 Eastern Pakistan and Bangladesh (Supplementary Fig. 4b). Western Himalayan region (mainly the

190 Thar desert region), East-central India, and West Pakistan show negligible water consumption

191 changes in DJF and MAM due to reductions in water availability. Further, water consumption is

192 strongly amplified by the increase in ET, mostly linked to extensive agricultural activities and the

193 increase in mean temperature ${ }^{48-50}$. The spatial pattern of water consumption (Fig. 2a) largely

194 follows the spatial pattern of the population (Supplementary Fig. 8a) and ET (Supplementary Fig.

$1952 \mathrm{c})$.

197 The ensemble precipitation projections for JJAS show significant increases (Supplementary Fig.

198 2a) over Central India and Bangladesh, and slight increases over the Western Himalayas, 199 Southeastern India, and Sri Lanka. However, a significant decline in rainfall is seen in 200 Southwestern coastal and North-central India, and the Middle and Eastern Himalayan region. In 201 SA, JJAS is the main rainfall season, with approximately $80 \%$ of the rainfall occurring during this 202 season ${ }^{47}$. During ON, Sri Lanka, the coastal regions of India, Southeastern, and Southwestern India 203 show a considerable increase in precipitation. In addition, the river discharge during JJAS 204 decreases in the Himalayan region, North-central India, Eastern Pakistan, and Southern India, 205 areas that include some prominent river basins (the Indus, Ganga-Brahmaputra, and Lower 206 Krishna basins). An increase in discharge is observed in Central India, while the rest of SA shows 207 a minor change. In other seasons, the river discharge generally shows a declining trend in the 208 Himalayas and North-central India with few exceptions. For example, the Western Himalayan 209 region slightly increases during ON, DJF, and MAM, while the Eastern Himalayan region shows 210 increased discharge during MAM.

212 ET shows considerable increases during all the seasons, except for the Himalayan region, Western 213 India (mainly Thar dessert), and Southwestern Pakistan (Supplementary Fig. 3c). ET is high during 214 the dry seasons, particularly in the North-central, Northwestern India, Eastern Pakistan, and 215 Bangladesh, areas that have the highest population and the most irrigation activities. Global 216 warming $^{48,49}$ and irrigation activities ${ }^{50,51}$ are the two drivers that lead to a massive increase in ET 217 in a warmer world. The changes in the hydrological fluxes strongly control WS variability. To 218 scrutinize the individual contribution on seasonal and spatial WS, we perform a statistical 
219 regression analysis with precipitation and ET as explanatory variables, given the availability is a 220 direct outcome of discharge and consumption (see Methods). Results reveal a robust 221 spatiotemporal control of precipitation and ET on WS (Fig. 3). Largely, WS is dominated by 222 changes in precipitation in JJAS over most regions, while ET plays a significant role in DJF for 223 most of the regions. In MAM and $\mathrm{ON}$, the changes in precipitation are dominant over the 224 Himalayan region, North-eastern India, Bangladesh, and southern India. The changes in the ET 225 are dominant over Pakistan, western, and Central India.

227 The aforementioned results are for the $1.5{ }^{\circ} \mathrm{C}$ warming scenario and a similar pattern of change is 228 observed in a $2{ }^{\circ} \mathrm{C}$ warming scenario (Supplementary Information).

\section{Discussion}

231 This study provides the first seasonal WS assessment in SA under the Paris Agreement temperature

232 targets and identifies the responsible hydrological components for the driving force of declining 233 water availability. For example, precipitation and ET show an increasing trend in most regions. 234 The large rise in precipitation and ET can be a result of an increase in mean temperature ${ }^{48,49}$ and 235 increased agricultural activities in the region ${ }^{50,51}$. The river discharge projections show a steady 236 decline in most regions during the monsoon and post-monsoon seasons. Previous studies have 237 reported increases in discharge in SA for similar warming scenarios but under different 238 concentration pathways, in which the warming targets occur early ${ }^{5,19,20}$. Nevertheless, most of 239 these studies did not consider seasonal variations, which could be the reason for the difference.

240 Furthermore, in the northern river basins, the decline could be linked to the reduced glacier 241 meltdown, e.g., $80 \%$ of Indus basin river flow has been attributed to glacier melt down ${ }^{52}$ that is 242 projected to peak around the year 2030 for middle and low emission scenarios ${ }^{53}$. Despite increases 243 in the precipitation, the counter impact of the increases in ET and decreases in the discharge is 244 more dominant, resulting in overall negative effects on water availability. Our study finds a large 245 increase in water consumption with a strong spatiotemporal variability mostly in the highly 246 populated regions of North-central India, Eastern Pakistan, and Bangladesh, even when the human 247 impact is set at the year 2005. The increased WS (Fig. 1) in SA is a result of the combined impact 248 of decreased water availability and increased consumption. The consumption factor plays a crucial 
role in the densely populated regions, while changes in water availability are more widely

250 distributed with substantial spatiotemporal variability and a plausible broader impact on WS.

252 Projected changes in seasonal WS, in the $1.5^{\circ} \mathrm{C}$ warming scenario, will have a severe societal 253 impact with a sizeable reshuffling in the number of people affected in the region. These changes 254 represent a significant increase compared to the pre-industrial period. For example, DJF and MAM 255 are projected to be the most affected seasons in terms of WS, corresponding to the winter cropping 256 season locally referred to as Rabi, thus, jeopardizing the water and food security of millions of people living in the region. Our findings are in agreement with previous studies that report severe WS in $\mathrm{SA}^{6,8,15,16,34,37,43}$. However, we observe some disagreements with the studies using RCP 8.5 warming scenarios that report an increase in water availability in $\mathrm{SA}^{5,19,20}$. None of these studies analyzed seasonal changes in water availability, one of the critical dimensions of WS in this monsoonal region. The results suggest that changes in the ET act parallel with the changes in precipitation to augment WS. The seasonal and spatial control of these hydrological fluxes shows extreme variability with precipitation as a dominant factor in JJAS and ET as a dominant factor in DJF for most regions. Precipitation in MAM and ON controls WS over the Himalayan region, North-eastern India, Bangladesh, and southern India, while ET controls WS over Pakistan, western, and Central India. Thus, this study provides a better understanding of the underlying factors that augment WS both at seasonal and spatial scales. The results suggest that the Paris Agreement temperature target of $1.5^{\circ} \mathrm{C}$ will be a critical point for WS in SA, which is alarming given that global temperature has already increased by $1{ }^{\circ} \mathrm{C}$ compared to the pre-industrial period.

\section{Conclusions}

272 We conclude that global warming of $1.5^{\circ} \mathrm{C}$ will cause profound impacts on 875 million people 273 across SA. Hence, sustaining even under this largely anticipated warming target will pose 274 unprecedented challenges to the region, particularly under current water policies, socio-economic 275 paradigms, and population trends. Our results are important in identifying the spatial and temporal 276 hotspots of WS in the region, which will benefit policymakers in designing sustainable water 277 allocation and management policies. While our study represents WS scenarios using most novel 278 data sets, we do agree that including future human interference will further improve WS 
estimations. Even though both warming scenarios present a similar degree of WS in terms of the

280 percentage of population affected, a $2{ }^{\circ} \mathrm{C}$ warmer world is projected to see an intensification in

281 precipitation and ET. We suggest future work in line with the Paris Agreement 2015 must be 282 carried to investigate both seasonal and temporal changes in the intensification of hydrological

283 fluxes to understand and assess the alterations in the hydrological extremes. We suggest that 1.5

$284{ }^{\circ} \mathrm{C}$ of global warming is alarming, particularly for SA and a scenario of water crises can prevail 285 given the extreme population and socio-economic vulnerability of the region. Thus immediate 286 mitigations and legislations are needed to curtail the impact of changing climate on water scarcity, particularly in the hot spots identified in this study.

289 Datasets and Methods

290 Scenario Design and Data

291 In this study, we evaluate WS in SA (India, Pakistan, Bangladesh, Nepal Bhutan, Sri Lanka, and 292 the Maldives) under the Paris Agreement temperature targets of 1.5 and $2{ }^{\circ} \mathrm{C}$ temperature increase 293 compared to the pre-industrial period. We also examine the spatial as well as temporal WS hotspots. 294 Further, we evaluate the two important dimensions of WS, availability and consumption, and the 295 hydrological variables and compute their absolute changes compared to the preindustrial period. 296 To do so, we use the outputs from the two global hydrological models (GHMs where the water 297 consumption is available) PCR-GLOBWB ${ }^{54,55}$ and WaterGAP2 ${ }^{56}$, forced by three global climate 298 models (GCMs), MIROC5, HadGEM2-ES, and GFDL-ESM2M from Inter-Sectoral Model 299 Intercomparison Project Phase 2b (ISIMIP2b) under the RCP 6.0 middle emission scenario ${ }^{46}$. Thus 300 we generate data for three worlds: one representing natural conditions in the pre-industrial 301 reference period (1661-1860; as mentioned in the ISIMIP protocol with pre-industrial socio302 economic conditions fixed at 1860$)^{46}$ and two future scenarios: 1) a $1.5^{\circ} \mathrm{C}$ warmer world and 2) a $3032{ }^{\circ} \mathrm{C}$ warmer world; using the RCP 6.0 middle emission scenario ${ }^{46}$. For the RCP6.0 scenario, future 304 climate and $\mathrm{CO}_{2}$ concentration vary as per RCP 6.0, while human interferences including land use 305 represent 2005 societal conditions. 
307 We choose the two GHMs specifically because they provide actual water consumption data. 308 Furthermore, we select the three GCMs for the reason that they cross the 1.5 and $2{ }^{\circ} \mathrm{C}$ temperature 309 thresholds under RCP 6.0, a prerequisite for this study. The individual GCMs cross the 1.5 and 2 $310{ }^{\circ} \mathrm{C}$ temperature thresholds compared to the preindustrial period at different times. For example, a $3111.5^{\circ} \mathrm{C}$ temperature increase is observed in 2056, 2052, and 2032 for GFDL-ESM2M, MIROC5,

312 and HadGEM2-ES, respectively. The time of crossing a warming level is defined as the first time 313 the 31-year running mean of global mean temperature crosses the given thresholds. The threshold 314 represents the central year within this 31-year (i.e., 15 before the level was reached, and 15 after) 315 period (Table S3; https://www.isimip.org/protocol/isimip2b-temperature-thresholds-and-time316 slices/).

318 The variables used in this analysis include: water consumption, water availability, precipitation, 319 evapotranspiration (ET), and discharge, all the variables are available from ISIMIP2b at a spatial 320 resolution of $0.50 \times 0.50$, except water availability, which is calculated separately. We calculate 321 seasonal water consumption, discharge, and ET for each GCM-GHM combination independently. 322 All the variables are simulated for each season of the year for an average of 31 years, corresponding 323 to the middle of the 31-year temperature time frame of each GCM. Next, we calculate water 324 availability by summing water consumption and discharge from each GCM-GHM combination. 325 Subsequently, we calculate WS as a ratio of water consumption to water availability using water 326 consumption/availability from each GCM-GHM combination. Lastly, we calculate the ensemble 327 mean of all the variables for each warming scenario respectively. Seasonal values represent the 328 average of all the months $\left(\mathrm{mm} \mathrm{month}^{-1}\right)$ in a particular season according to the climatological cycle 329 in SA.

\section{Water scarcity}

332 Water scarcity (WS) refers to the deficit in freshwater resources compared with the environmental 333 or anthropogenic water demand ${ }^{42}$. In this study, water scarcity is estimated as the ratio of actual 334 water consumption to actual water availability in each grid cell for each season following Kummu 335 et al. $2016^{16}$. WS is classified into three categories: 1) WSI $<0.2$ : No Water Scarcity (NWS); 2) 336 WSI=0.2-0.4: Moderate Water Scarcity (MWS); and 3) WSI >0.4: Severe Water Scarcity (SWS). 
337 Here we unequivocally use water consumption, so that the water consumed within a grid cell is no 338 longer available to other users ${ }^{16,57}$. In SA, due to immense irrigation, a large proportion of water 339 is abstracted ${ }^{58-60}$; therefore, taking withdrawal might result in overestimation of water scarcity as

340 a part of withdrawal is either available to downstream users or as return flow to the groundwater 341 system $^{57,61}$.

$$
W S I(i, s)=A W C(i, s) / A W A(i, s)
$$

344 Where WSI is the water scarcity index in cell " $\mathrm{i}$ " and for the season " $\mathrm{s}$ "; AWC (mm/month) is the 345 actual water consumption in cell "i" for the season "s"; and AWA (mm/month) is the actual water 346 available in cell " $i$ " for the season "s". For example, if more than $40 \%$ of the available water is 347 consumed, WS is graded as severe; and similarly, if the consumption ranges between 20-40\%, WS 348 is said to be moderate; and when the consumption is less than $20 \%$, there is no WS, the $20 \%$ 349 threshold is set based on the amount of water that is required to maintain environmental flows, as 350 identified in the previous studies ${ }^{16,43,54,62}$. Water consumption (AWC) is the total water consumed 351 by all of the sectors such as agriculture, livestock, domestic, and industrial and the water 352 availability (AWA) is the total amount of water that is available in each grid including the 353 contribution from upstream cells and is calculated for each grid cell by adding total water 354 consumption and discharge. Discharge $(\mathrm{mm} / \mathrm{month})$ is the total available water resource in a grid 355 cell (remaining after the upstream and downstream water deduction) including surface and 356 groundwater.

\section{Population under water scarcity}

359 We calculate population under different WS categories for each season of the year for an average 360 of 31 years, corresponding to the middle of the 31-year temperature time frame of each GCM 361 (Table S3) under SSP population distribution, except for the pre-industrial reference period, which 362 corresponds to year-1860 population. We then calculate the ensemble average absolute population 363 and the percentage of the total population under different WS categories in each season of the year 364 for each warming scenario. Thus we show population moving "into" and "out of" the different WS 365 categories seasonally, for example, in JJAS, 157 million (7.6\% of the total population in SA) 
366 people are projected to face severe WS, and the number increases to 341 million (16.5\%), 610 367 million (29.4\%), and 558 million (28.4\%) in ON, DJF, and MAM, respectively in a $1.5^{\circ} \mathrm{C}$ warming 368 scenario (Table 1). Results for the $2{ }^{\circ} \mathrm{C}$ scenario are shown in supplementary table 2.

370 We also calculate absolute population and the percentage of the total population under different

371 WS categories in each season of the year for the pre-industrial reference period (supplementary

372 Table 1). Thus we provide the assessment of the increase in the absolute and the percentage of the

373 total population under different WS categories in each warming scenario compared to the pre374 industrial period. For example, the total population living under severe WS will increase from 4 $375(1.5 \%)$ to $157(7.6 \%), 10.5(3.7 \%)$ to $341(16.5 \%), 16(5 \%)$ to $610(29.4 \%)$, and $18(6 \%)$ to 558

376 (28.4\%) million in JJAS, ON, DJF, and MAM, respectively in $1.5{ }^{\circ} \mathrm{C}$ warming scenario compared 377 to the preindustrial period.

\section{Hydrological Variables}

380 Here we first perform the individual GCM-GHM simulations for discharge and ET, and only GCM 381 simulations for precipitation for 1.5 and $2{ }^{\circ} \mathrm{C}$ warming scenarios, producing 120 datasets 382 (Supplementary Figs 9-14). The analysis is conducted at a seasonal scale and the ensemble 383 projections are then used to show the spatio-temporal alterations in the hydrological variables for 384 both warming scenarios (Supplementary Figs. 2-3). The scenario analysis reveals a significant 385 alteration in the hydrological variables that contributes to the strong seasonality in water 386 availability. We further notice intensification in precipitation and ET in particular under a $2{ }^{\circ} \mathrm{C}$ 387 warming scenario. Hence it is important to have a detailed future study focusing on the assessment 388 of hydrological fluxes vis-à-vis hydrological extremes under the Paris Agreement.

\section{Regression Analysis}

391 For linear regression, we consider two climate-driven hydrological fluxes that is precipitation and 392 ET as explanatory variables for WS, given that discharge is one of the parameters in WS 393 assessment (see Equ.1; Methods). Following the methodology of $\mathrm{Wu}$ et al 2020 $0^{63}$, we use the 
394 following equation to perform regression analysis of seasonal precipitation and ET on WS for both $395 \quad 1.5$ and $2^{\circ} \mathrm{C}$ warming scenarios.

$$
y^{*}=a_{1}^{*} x_{1}^{*}+a_{2}^{*} x_{2}^{*}(2)
$$

399 Where " $\mathrm{y}^{*}$ " is the standardized (subtracting the mean and dividing by its standard deviation)

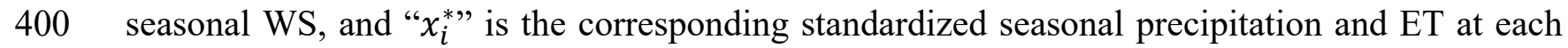
401 grid cell. $a_{1}^{*}$ and $a_{2}^{*}$ are the partial regression coefficient for precipitation and ET respectively. 402 Only the grid cells with the statistical significance F-test at a 95\% confidence level are considered 403 for this analysis. The contribution of different variables $\left(R_{i}\right)$ are calculated as follows:

404

$$
R_{i}=\frac{\left|a_{i}^{*}\right|}{\sum_{i}^{N}\left|a_{i}^{*}\right|} * 100 \% \text { (3) }
$$

405 The contribution of precipitation and ET on the WS is shown in Fig. 3 and Supplementary Fig. 7.

\section{Data availability}

408 The datasets used in this study are obtained from the ISIMIP phase2 framework and are available 409 via www.isimip.org.

\section{Code availability}

412 The code that supports the findings of this study is available at 413 https://doi.org/10.5281/zenodo.5652805 


\section{Acknowledgments}

418 This work is supported by the Ministry of Science and Technology, Taiwan (MOST) 104-2923-M419 002-002-MY4 to the National Taiwan University; by the IGEM project "Impact of Groundwater 420 in Earth system Models". M.R. acknowledges support from MOST, Taiwan as a part of the 421 Postdoctoral Program (Grant 107-2811-M-002-016 \& MOST 108-2811-M-002-501). M.-H. L. and 422 R.-J. W. are supported by the MOST, Taiwan (Grant 110-2628-M-002-004-MY4 and MOST 110423 2111-M-002-012)

424

\section{Author contributions}

426 M.R. and M.H.L. conceived and performed the research. Y.W. and H.M.S provided comments on 427 the manuscript. R.J.W analyzed the ISIMIP2b data with guidance from M.H.L and M.R. Y.W. and 428 H.M.S contributed to the model simulations as a part of the ISIMIP team. M.R and M.H.L drafted 429 the manuscript and all authors contributed to the discussion and interpretation of the results and 430 provided comments on the manuscript.

\section{Competing interests}

433 The authors declare no competing interests. 


\section{References}

441 1. IPCC. Global warming of $1.5^{\circ} \mathrm{C}$ : an IPCC special report on the impacts of global

$442 \quad$ warming of $1.5^{\circ} \mathrm{C}$ above pre-industrial levels and related global greenhouse gas emission

443 pathways, in the context of strengthening the global response to the threat of climate

444 chang. (2018).

445 2. UNFCCC. The Paris Agreement. United Nations Framework Convention on Climate

446 Change. (2015) http://unfccc.int/paris_agreement/items/9485.php.

447 3. Alcamo, J., Flörke, M. \& Märker, M. Future long-term changes in global water resources

448 driven by socio-economic and climatic changes. Hydrol. Sci. J. 52, 247-275 (2007).

449 4. Haddeland, I. et al. Global water resources affected by human interventions and climate

$450 \quad$ change. Proc. Natl. Acad. Sci. U. S. A. 111, 3251-3256 (2014).

451 5. Schewe, J. et al. Multimodel assessment of water scarcity under climate change. Proc.

$452 \quad$ Natl. Acad. Sci. 111, 3245-3250 (2014).

453 6. Mekonnen, M. M. \& Hoekstra, A. Y. Four billion people facing severe water scarcity. Sci. $454 \quad A d v$. 2, e1500323-e1500323 (2016).

$4557 . \quad$ Veldkamp, T. I. E., Wada, Y., JCJH Aerts \& Ward, P. J. Towards a global water scarcity 456 risk assessment framework: incorporation of probability distributions and hydro-climatic $457 \quad$ variability. Environ. Res. Lett. 11, (2016).

458 8. Hoekstra, A. Y., Mekonnen, M. M., Chapagain, A. K., Mathews, R. E. \& Richter, B. D. 459 Global monthly water scarcity: Blue water footprints versus blue water availability. PLoS $460 \quad$ One 7, (2012).

4619 9. Wada, Y., Van Beek, L. P. H. \& Bierkens, M. F. P. Modelling global water stress of the 462 recent past: On the relative importance of trends in water demand and climate variability. 463 Hydrol. Earth Syst. Sci. 15, 3785-3808 (2011).

464 10. Liu, J. et al. Water scarcity assessments in the past, present, and future. Earth's Futur. 5, $465 \quad 545-559(2017)$.

466 11. Vorosmarty, C., Green, P., Salisbury, J. \& Lammers, R. Global water resources: 467 vulnerability from climate change and population growth. Science (80-. ). 289, 284-288 468 (2000).

469 12. Alcamo, J., Flörke, M. \& Märker, M. Future long-term changes in global water resources 
driven by socio-economic and climatic changes. Hydrol. Sci. J. 52, 247-275 (2007).

13. Hejazi, M. I. et al. Integrated assessment of global water scarcity over the 21 st century under multiple climate change mitigation policies. Hydrol. Earth Syst. Sci. 18, 2859-2883 (2014).

14. Wada, Y. et al. Global monthly water stress: 2. Water demand and severity of water stress. Water Resour. Res. 47, 1-17 (2011).

15. Satoh, Y. et al. Multi-model and multi-scenario assessments of Asian water futures: The Water Futures and Solutions (WFaS) initiative. Earth's Futur. 5, 823-852 (2017).

16. Kummu, M. et al. The world's road to water scarcity: shortage and stress in the 20th century and pathways towards sustainability. Sci. Rep. 6, 38495 (2016).

17. UNWWDP. The United Nations World Water Development Report: Water for a Sustainable World. Paris, UNESCO. (2015).

18. Wada, Y., van Beek, L. P. H., Wanders, N. \& Bierkens, M. F. P. Human water consumption intensifies hydrological drought worldwide. Environ. Res. Lett. 8, 034036 (2013).

19. Gosling, S. N. \& Arnell, N. W. A global assessment of the impact of climate change on water scarcity. Clim. Change 134, 371-385 (2016).

20. Schleussner, C. F. et al. Differential climate impacts for policy-relevant limits to global warming: The case of $1.5^{\circ} \mathrm{c}$ and $2^{\circ} \mathrm{c}$. Earth Syst. Dyn. 7, 327-351 (2016).

21. Shiklomanov, I. A. World fresh water resources, inWater in Crisis, edited by P.H. Gleick. Oxford Univ. Press. New York 13-24 (1993).

25. Huntington, T. G. Evidence for intensification of the global water cycle: Review and synthesis. J. Hydrol. 319, 83-95 (2006).

26. Vörösmarty, C. J., Green, P., Salisbury, J. \& Lammers, R. Global Water Resources : 
(2000).

502 27. Scherer, L. \& Pfister, S. Dealing with uncertainty in water scarcity footprints. Environ. Res. Lett. 11, 054008 (2016).

28. Wada, Y., Gleeson, T. \& Esnault, L. Wedge approach to water stress. Nat. Geosci. 7, 615617 (2014).

29. Wada, B. Y. Reducing water scarcity possible by 2050 : Linking global assessments to policy dimensions. 1-5 (2016) doi:10.1038/ngeo2241.

508 30. World Bank Annual Report. 1-18 (2018).

509 31. Saeed, F., Schleussner, C.-F. \& Ashfaq, M. Deadly heat stress to become commonplace across South Asia already at $1.5^{\circ} \mathrm{C}$ of global warming. Geophys. Res. Lett. (2021) doi:10.1029/2020GL091191.

32. Singh, R. \& Kumar, R. Climate versus demographic controls on water availability across India at $1.5^{\circ} \mathrm{C}, 2.0^{\circ} \mathrm{C}$ and $3.0^{\circ} \mathrm{C}$ global warming levels. Glob. Planet. Change $177,1-9$ (2019).

33. Wada, Y. \& Bierkens, M. F. P. Sustainability of global water use: past reconstruction and future projections. Environ. Res. Lett. 9, 104003 (2014).

34. India, G. Composite Water Management Index: A tool for water management. Natl. Inst. Transform. India http://www.niti.gov.in/writereaddata/files/documen (2018).

35. Wada, Y. \& Bierkens, M. F. P. Sustainability of global water use: past reconstruction and future projections. Environ. Res. Lett. 9, 104003 (2014).

36. Asian Development Outlook 2013: Asia's Energy Challenge. 202-208 (2013).

37. Oki, T. \& Kanae, S. Global Hydrological Cycles and World Water Resources. Science (80-. ). 313, 1068-1072 (2006).

38. Rodell, M., Velicogna, I. \& Famiglietti, J. S. Satellite-based estimates of groundwater depletion in India. Nature 460, 999-1002 (2009).

40. Gerten, D. et al. Global Water Availability and Requirements for Future Food Production.

530 41. KC, S., Wurzer, M., Speringer, M. \& Lutz, W. Future population and human capital in heterogeneous India. Proc. Natl. Acad. Sci. 115, 8328-8333 (2018). 
532 42. Veldkamp, T. I. E. et al. Water scarcity hotspots travel downstream due to human 533 interventions in the 20th and 21st century. Nat. Commun. 8, 15697 (2017).

534 43. Kummu, M., Ward, P. J., de Moel, H. \& Varis, O. Is physical water scarcity a new 535 phenomenon? Global assessment of water shortage over the last two millennia. Environ.

$536 \quad$ Res. Lett. 5, 034006 (2010).

537 44. Konzmann, M. et al. Global water resources affected by human interventions and climate 538 change. Proc. Natl. Acad. Sci. 111, 3251-3256 (2013).

539 45. Schleussner, C.-F. et al. Science and policy characteristics of the Paris Agreement temperature goal. Nature 6, 827-835 (2016).

46. Frieler, K. et al. Assessing the impacts of $1.5 \circ \mathrm{C}$ global warming - simulation protocol of the Inter-Sectoral Impact Model Intercomparison Project ( ISIMIP2b ). Geosci. Model Dev. 4321-4345 (2017) doi:10.5194/gmd-10-4321-2017.

544 47. Jin, Q. \& Wang, C. A revival of Indian summer monsoon rainfall since 2002. Nat. Clim. Chang. 7, 587-594 (2017).

48. Pfleiderer, P., Schleussner, C.-F., Kornhuber, K. \& Dim Coumou. Summer weather becomes more persistent in a $2{ }^{\circ} \mathrm{C}$ world. Nat. Clim. Chang. 666-672 (2019) doi:10.1038/s41558-019-0555-0.

49. Pascolini-Campbell, M., Reager, J. T., Chandanpurkar, H. A. \& Rodell, M. A 10 per cent increase in global land evapotranspiration from 2003 to 2019. Nature 593, 543-547 (2021).

552 50. Zaveri, E. et al. Invisible water, visible impact: Groundwater use and Indian agriculture under climate change. Environ. Res. Lett. 11, (2016).

554 51. Asoka, A., Gleeson, T., Wada, Y. \& Mishra, V. Relative contribution of monsoon precipitation and pumping to changes in groundwater storage in India. Nat. Geosci. 10,

557 52. Saeed, F., Hagemann, S. \& Jacob, D. Impact of irrigation on the South Asian summer 558 monsoon. Geophys. Res. Lett. 36, 1-7 (2009).

559 53. Kraaijenbrink, P. D. A., Bierkens, M. F. P., Lutz, A. F. \& Immerzeel, W. W. Impact of a $560 \quad 1.5^{\circ} \mathrm{C}$ global temperature rise on Asia's glaciers. Nature 549, 257-260 (2017).

561 54. Van Beek, L. P. H., Wada, Y. \& Bierkens, M. F. P. Global monthly water stress: 1. Water balance and water availability. Water Resour. Res. 47, (2011). 
563 55. Wada, Y., Wisser, D. \& Bierkens, M. F. P. Global modeling of withdrawal, allocation and 564 consumptive use of surface water and groundwater resources. Earth Syst. Dyn. 5, 15-40 (2014).

566 56. Muller Schmied, H. et al. Variations of global and continental water balance components 567 as impacted by climate forcing uncertainty and human water use. Hydrol. Earth Syst. Sci. 20, 2877-2898 (2016).

569 57. Hoekstra, A. Y. \& Mekonnen, M. M. The water footprint of humanity. 109, (2012).

570 58. Shah, T. Climate change and groundwater: India's opportunities for mitigation and adaptation. Environ. Res. Lett. 4, 1-13 (2009).

572 59. Jain, M. et al. Groundwater depletion will reduce cropping intensity in India. Sci. Adv. 7, $573 \quad 1-10(2021)$.

574 60. Shekhar, S. et al. Modelling water levels of northwestern India in response to improved 575 irrigation use efficiency. Sci. Rep. 1-15 (2020) doi:10.1038/s41598-020-70416-0.

576 61. Kendy, E., Conservancy, T. N. \& Measures, C. P. The False Promise of Sustainable Pumping Rates. Ground Water 41, 2-4 (2003).

62. Falkenmark, M. et al. On the Verge of a New Water Scarcity: A Call for Good Governance and Human Ingenuity. SIWI Policy Br. 20 (2007).

63. $\mathrm{Wu}, \mathrm{W}$. Y. et al. Divergent effects of climate change on future groundwater availability in key mid-latitude aquifers. Nat. Commun. 11, 1-9 (2020). 
Table and Figure captions:

591 Table 1 shows the seasonal distribution of the South Asian population (in millions) under

592 various WS categories at $1.5^{\circ} \mathrm{C}$ temperature increase under RCP 6.0 and SSP2 climate and

593 population projections. SWS refers to severe water scarcity, MWS refers to moderate water

594 scarcity, and the total water scarcity is the sum of SWS and MWS. The population

595 projections correspond to the central year of the 31-year mean corresponding to the

596 individual GCM temperature threshold as shown in table S3.

598 Figure 1. Water scarcity (measured as water scarcity index- WSI) in South Asia at $1.5^{\circ} \mathrm{C}$ 599 temperature increase under RCP 6.0 (a) Seasonal ensemble mean absolute changes in WS at $600 \quad 1.5{ }^{\circ} \mathrm{C}$ (b) Seasonal ensemble mean absolute changes in WS at $1.5{ }^{\circ} \mathrm{C}$ compared to pre601 industrial period. The ensemble represents the seasonal averaged WS from the individual 602 GHM-GCM combination. WSI is calculated as a ratio of water consumption (mm month ${ }^{-1}$ ) 603 to water availability $\left(\mathbf{m m ~ m o n t h} \mathbf{~}^{-1}\right)$.

605 Figure 2. Water availability and water consumption in South Asia at $1.5^{\circ} \mathrm{C}$ temperature 606 increase under RCP 6.0 scenario (a) The ensemble mean absolute changes in the seasonal 607 water availability compared to the pre-industrial period. (b) The ensemble mean absolute 608 changes in the seasonal water consumption compared to the pre-industrial period. All the 609 variables are represented as an ensemble, averaged over each season (mm month $\left.{ }^{-1}\right)$ from 610 individual GHM-GCM combinations.

612 Figure 3. Contribution of precipitation and ET on WS in South Asia as derived from 613 regression analysis at $1.5{ }^{\circ} \mathrm{C}$ of temperature increase under RCP 6.0 scenario (a) 614 Spatiotemporal control of precipitation on WS. (b) Spatiotemporal control of ET on WS. 
617 Table 1 shows the seasonal distribution of the South Asian population (in millions) under 618 various WS categories at $1.5{ }^{\circ} \mathrm{C}$ temperature increase under RCP 6.0 and SSP2 climate and 619 population projections. SWS refers to severe water scarcity, MWS refers to moderate water 620 scarcity, and the total water scarcity is the sum of SWS and MWS. The population 621 projections correspond to the central year of the 31-year mean corresponding to the 622 individual GCM temperature threshold as shown in table S3.

623

\begin{tabular}{|c|c|c|c|c|c|c|c|c|c|}
\hline & \multirow{2}{*}{$\begin{array}{c}\text { Water } \\
\text { Scarcity } \\
\text { Grade }\end{array}$} & \multicolumn{2}{|c|}{ Winter (DJF) } & \multicolumn{2}{|c|}{ Pre Monsoon (MAM) } & \multicolumn{2}{|c|}{ Monsoon (JJAS) } & \multicolumn{2}{|c|}{ Post Monsoon (ON) } \\
\hline & & $\begin{array}{l}\text { Population } \\
\text { (millions) }\end{array}$ & $\begin{array}{l}\text { Percentage } \\
\text { of the total } \\
\text { population }\end{array}$ & $\begin{array}{l}\text { Population } \\
\text { (millions) }\end{array}$ & $\begin{array}{l}\text { Percentage } \\
\text { of the total } \\
\text { population }\end{array}$ & $\begin{array}{c}\text { Population } \\
\text { (millions) }\end{array}$ & $\begin{array}{l}\text { Percentage } \\
\text { of the total } \\
\text { population }\end{array}$ & $\begin{array}{c}\text { Population } \\
\text { (millions) }\end{array}$ & $\begin{array}{l}\text { Percentage } \\
\text { of the total } \\
\text { population }\end{array}$ \\
\hline \multirow[t]{2}{*}{ Bhutan } & SWS & 0 & 0 & 0 & 0 & 0 & 0 & 0 & 0 \\
\hline & MWS & 0 & 0 & 0 & 0 & 0 & 0 & 0 & 0 \\
\hline \multirow[t]{2}{*}{ Bangladesh } & SWS & 50 & 27.9 & 38 & 21.0 & 0 & 0 & 1.8 & 1.0 \\
\hline & MWS & 28 & 15.8 & 29 & 16.3 & 5.7 & 3.2 & 8 & 4.7 \\
\hline \multirow[t]{2}{*}{ India } & SWS & 494 & 31.3 & 503 & 31.8 & 129 & 8.1 & 278 & 17.6 \\
\hline & MWS & 209 & 13.2 & 217 & 13.7 & 143 & 9.1 & 202 & 12.8 \\
\hline \multirow[t]{2}{*}{ Pakistan } & SWS & 64 & 24.8 & 47 & 18.1 & 25 & 9.8 & 61 & 24.2 \\
\hline & MWS & 27 & 10.2 & 21 & 8.1 & 30 & 11.7 & 28 & 11.0 \\
\hline \multirow[t]{2}{*}{ Nepal } & SWS & 0.98 & 2.8 & 0.98 & 2.8 & 0 & 0 & 0 & 0 \\
\hline & MWS & 0 & 0 & 0 & 0 & 0 & 0 & 0 & 0 \\
\hline \multirow[t]{2}{*}{ Sri Lanka } & SWS & 0.62 & 3.5 & 0.37 & 2.1 & 2.50 & 14.1 & 0.5 & 2.8 \\
\hline & MWS & 0.50 & 2.8 & 1 & 5.6 & 1.8 & 9.9 & 0.7 & 4.0 \\
\hline \multirow[t]{3}{*}{ South Asia } & SWS & 610 & 29.4 & 588 & 28.4 & 157 & 7.6 & 341 & 16.5 \\
\hline & MWS & 265 & 12.8 & 268 & 13.0 & 181 & 8.7 & 239 & 11.5 \\
\hline & Total & 875 & 42.2 & 856 & 41.4 & 338 & 16.3 & 580 & 28 \\
\hline
\end{tabular}

624

625 

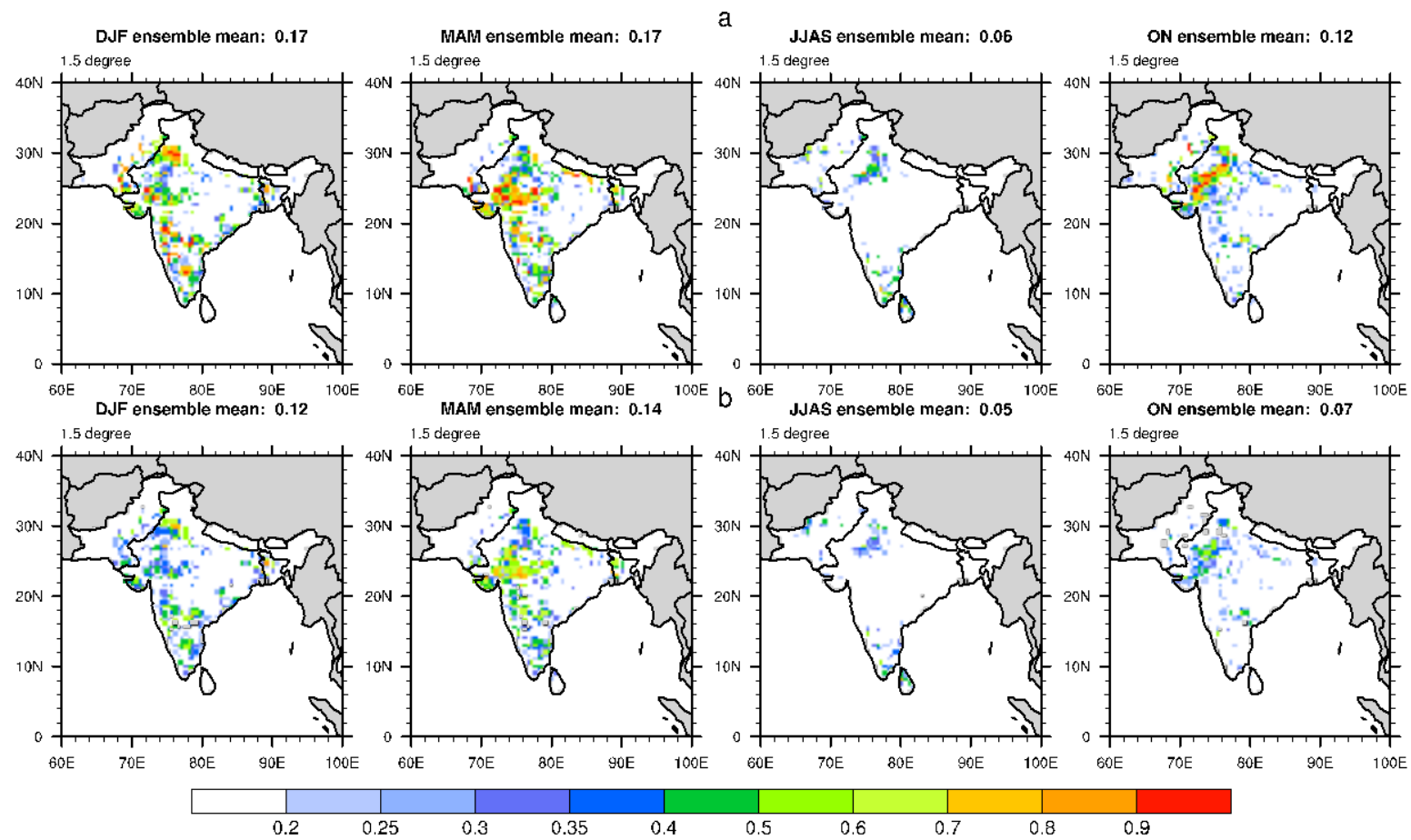

629 Figure 1. Water scarcity (measured as water scarcity index- WSI) in South Asia at $1.5{ }^{\circ} \mathrm{C}$ 630 temperature increase under RCP 6.0 (a) Seasonal ensemble mean absolute changes in WS at $631 \quad 1^{\circ} \mathrm{C}$ (b) Seasonal ensemble mean absolute changes in WS at $1.5{ }^{\circ} \mathrm{C}$ compared to pre632 industrial period. The ensemble represents the seasonal averaged WS from the individual 633 GHM-GCM combination. WSI is calculated as a ratio of water consumption (mm month $\left.{ }^{-1}\right)$ 634 to water availability ( $\left.\mathrm{mm} \mathrm{month}^{-1}\right)$.

635

636

637

638 

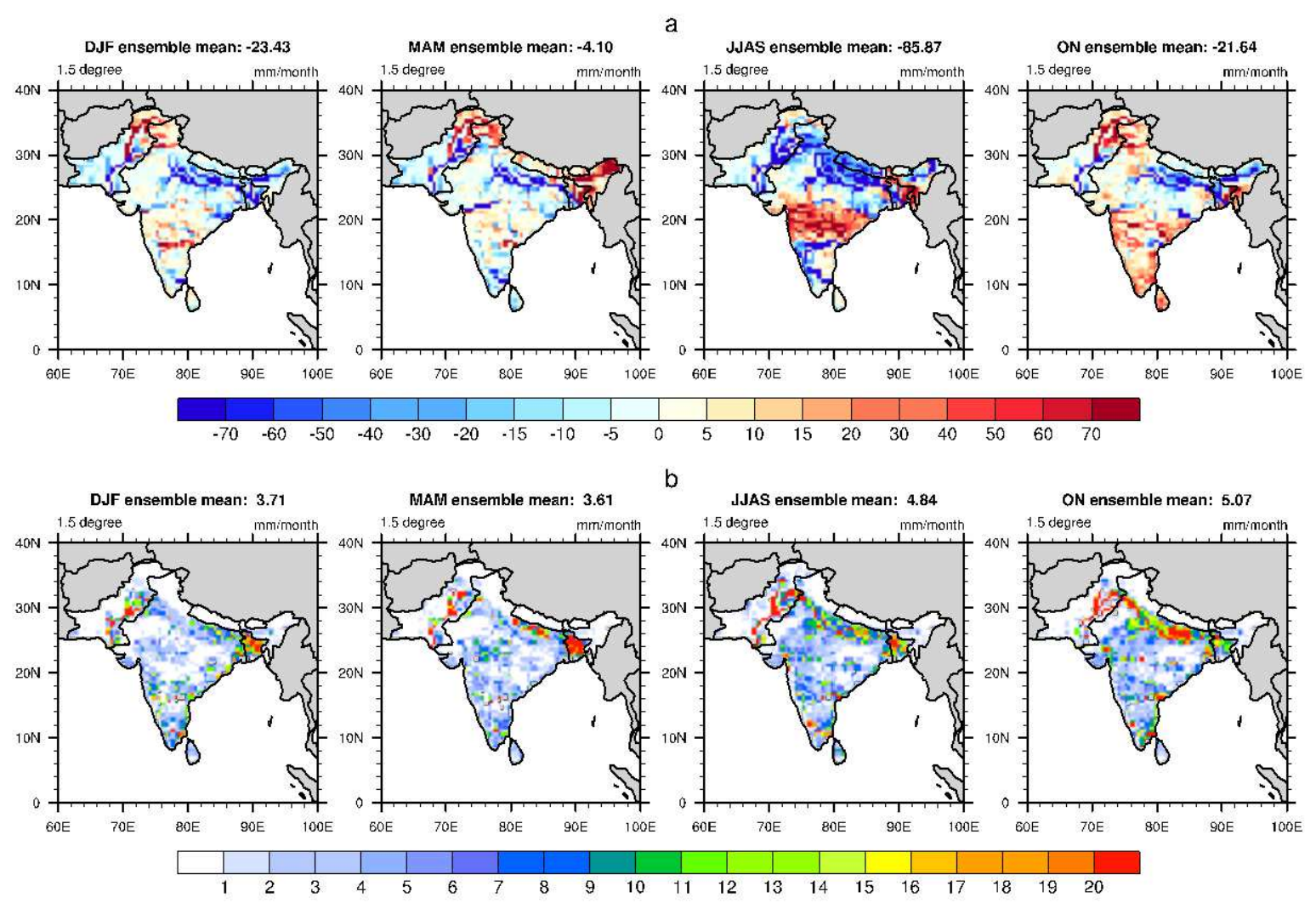

640 Figure 2. Water availability and water consumption in South Asia at $1.5^{\circ} \mathrm{C}$ temperature

641 increase under RCP 6.0 scenario (a) The ensemble mean absolute changes in the seasonal

642 water availability compared to the pre-industrial period. (b) The ensemble mean absolute

643 changes in the seasonal water consumption compared to the pre-industrial period. All the

644 variables are represented as an ensemble, averaged over each season (mm month ${ }^{-1}$ ) from

645 individual GHM-GCM combinations.

646

647

648

649

650 


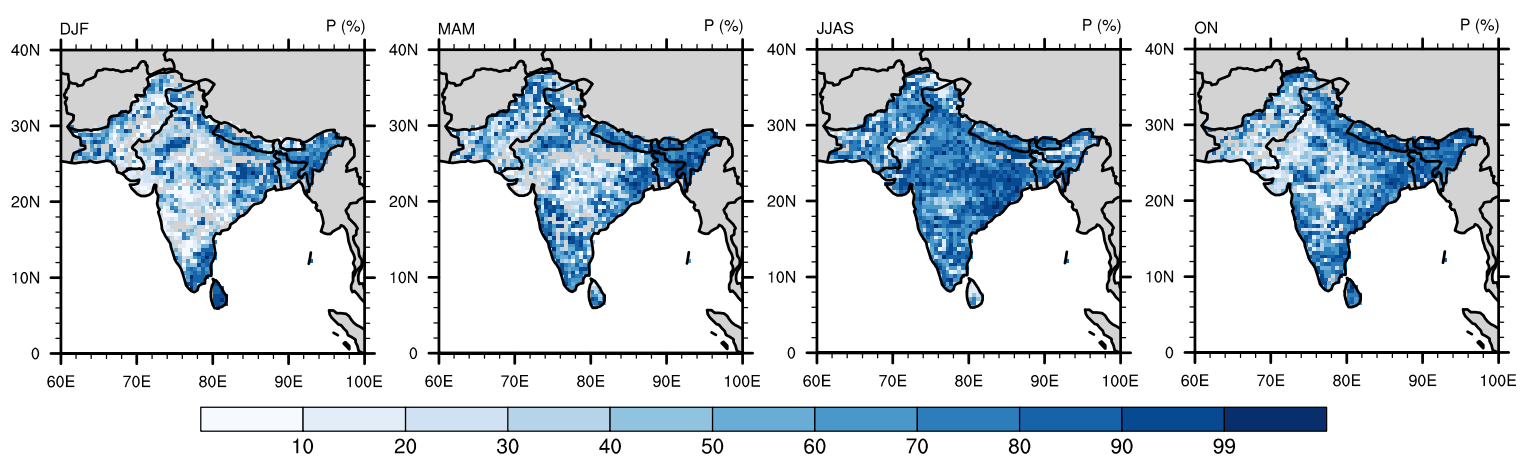

b

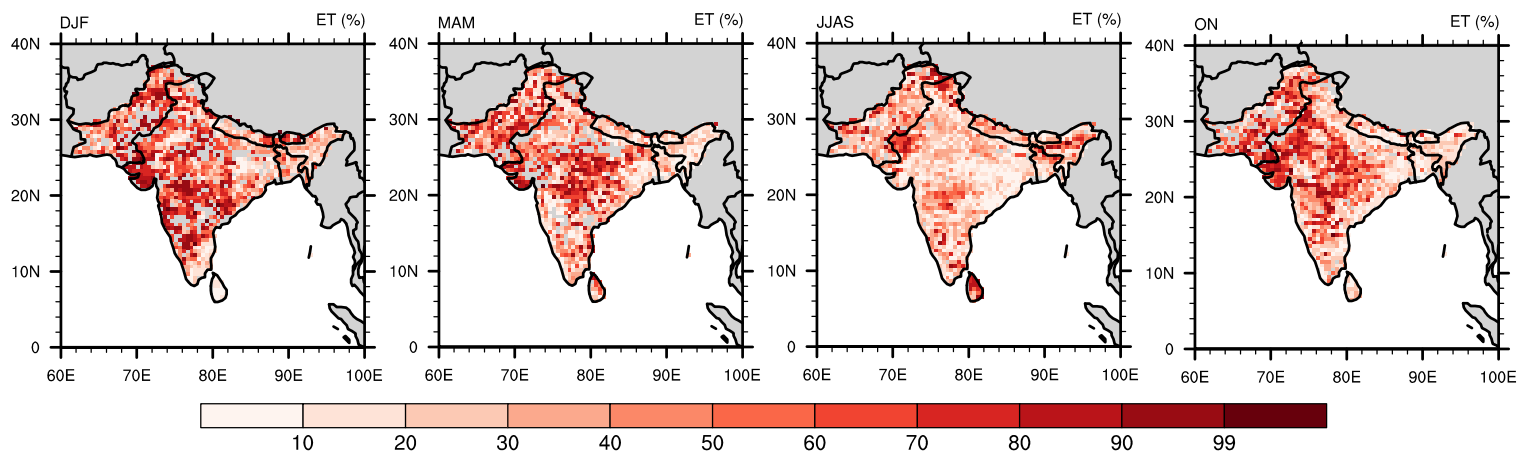

657 Figure 3. Contribution of precipitation and ET on WS in South Asia as derived from 658 regression analysis at $1.5{ }^{\circ} \mathrm{C}$ of temperature increase under $\mathrm{RCP} 6.0$ scenario (a) 659 Spatiotemporal control of precipitation on WS. (b) Spatiotemporal control of ET on WS. 


\section{Supplementary Files}

This is a list of supplementary files associated with this preprint. Click to download.

- SI.pdf 